\title{
Investigation of hemp (Cannabis sativa L.) crop weediness
}

\author{
Zofija Jankauskienė ${ }^{1}$, Elvyra Gruzdevienė ${ }^{2}$, Natalija Burbulis ${ }^{3}$, Ernestas Maumevičius ${ }^{4}$, \\ Iryna M. Layko 5 \\ ${ }^{1,2}$ Upyte Experimental Station of the Lithuanian Research Centre for Agriculture and Forestry \\ Address: Linininku 3, Upytè, Panevėžys district, LT-38 294, Lithuania \\ ${ }^{3,4}$ Aleksandras Stulginskis University \\ Address: Studentu 11, Akademija, Kaunas district, LT-53067, Lithuania \\ ${ }^{5}$ Research Station of Bast Crops of IA Northern East NAAS \\ Address: 45 Tereshchenkiv Street, 41400 Hlukhiv, Sumy region, Ukraine
}

\begin{abstract}
The investigation of hemp crop weediness was carried out at the Upyte Experimental Station of the Lithuanian Research Centre for Agriculture and Forestry in 2014. Bi-factorial trial was carried out: Factor A variety (A1 - USO 31; A2 - Bialobrzeskie); Factor B - sowing rate (B1 - $45 \mathrm{~kg} \mathrm{ha}^{-1}$; B2 - $\left.70 \mathrm{~kg} \mathrm{ha}^{-1}\right)$. Data showed that seed rate had a significant influence on crop density at full hemp emergence as well as at harvesting time. Rainy vegetation period was favourable not only for hemp growing, but for weeds as well. Crop density (resulted by seed rate) had a significant influence on crop weediness - significantly more weeds (in average 166 plants $\mathrm{m}^{-2}$ ) were found in the plots with seed rate of $45 \mathrm{~kg} \mathrm{ha}^{-1}$, consequently at lower crop density, and under 140 weed plants $\mathrm{m}^{-2}$ were found in the plots with seed rate of $70 \mathrm{~kg} \mathrm{ha}^{-1}$, consequently at higher crop density. Hemp crop weediness at harvesting time was much lower than that at the beginning of vegetation; reduction of weediness over the vegetation period was close to $87-90$ percent.
\end{abstract}

Keywords: Cannabis sativa L., crop density, seed rate, variety, weediness.

\section{INTRODUCTION}

Hemp (Cannabis sativa L.) is a plant having an ability to grow quite rapidly in some its ontogenesis periods. The rapid growth period starts from the appearance of the 6th set of leaves (BBCH stage 1012) [1], [2]. Weeds become stressing when hemp plants begin to overshadow them, and this suppressing lasts for the all rest vegetation period as hemp is quite tall plant. In central and southeaster Europe, where hemp is sown for fibre, hemp crop height could be 1.5-3.0 meters while in our previous trials in Lthuania the medium height of $2.78 \mathrm{~m}$ (for cultivar Beniko) was fixed [3].

Hemp produces a higher amount of biomass due to its higher growth rate $\left(0.5 \mathrm{~m} \mathrm{month}^{-1}\right)$ and it is rich in leafage. These characteristics make hemp dominant over the weeds [4], [5].

Hemp's ability to suppress weeds during its vegetative period could be expressed under few conditions. Firstly, hemp plants must thrive well for what they need a sufficient supply of water and nutrients, good soil structure, avoiding soil compression and excessive moisture. Grown in poor soil hemp has no chance to fight against weeds. Secondly, weed suppression can be executed only at relatively high crop densities. We tried to find information about what is "relatively high crop density" for hemp. The marginal seed rate is considered to be close to $40 \mathrm{~kg} \mathrm{ha}^{-1}$ : if hemp is sown with lesser seed rate, the crop is unable to expand sufficiently, and weeds have a greater chance for surviving [1]. A seed rate of $30 \mathrm{~kg} \mathrm{ha}^{-1}$ as suitable for hemp seed production is also mentioned [6], [7].

A normal crop density is considered 200-300 plants per square meter which shades out the weeds, leaving the fields weed-free at harvest for the next crop [8]. Experiments in the Netherlands demonstrated that hemp crops effectively suppressed weeds and that no herbicides were needed, except in the cases where plant densities were very low (10 or 30 plants per $\mathrm{m}^{2}$ ) [9].

In the trials in Australia, weed suppression was clearly affected by plant population as plant populations of 100 plants $\mathrm{m}^{-2}$ resulted in significantly greater weed biomass than did higher plant densities [7].

In Manitoba, the field choice, pre-sowing tillage, soil temperature, shallow sowing are main factors help ensuring that the hemp stand will emerge quickly and uniformly to gain advantage over the weeds [10]. 
Some authors also report that this crop requires no herbicides during vegetation time (in sufficient crop density) [1], [11], [12], [13], [14]. Firstly, weeds are destroyed by soil preparation in autumn and spring, and then overgrown by rapidly growing hemp plants. Exceptional could be hemp growing cases with wide (0.2-0.5 m) inter-row spaces (for seed purposes) where weed problem at the beginning could be solved by mechanical methods - using hoes or harrows [1].

Because of weed suppressing ability, hemp can be a prosperous proceeding crop for many crops, even for flax, as it is leaving clean and loose soil. Hemp can be grown with aim to reduce soil weediness as hemp plants are suppressing as annual as well as some perennial weeds [15], [16].

Some references point out that hemp supresses weeds so well that they rarely mature. So this weeds control carries over to all following crop, and it is why this plant is so interesting to organic farmers [1], [11].

The allelopathic potential of hemp is also mentioned [17].

The studying of crop weediness of few hemp varieties sown at different seed rates was the main task of our research presented here.

\section{MATERIALS AND METHODS}

The investigation on hemp crop weediness was carried out at the Upyte Experimental Station of the Lithuanian Research Centre for Agriculture and Forestry in 2014. The soil - an Eutri-Endohypogleyic Cambisol, CMg-n-w-eu [18]. The $\mathrm{pH}_{\mathrm{KC}}$ l level was 6.8 (potentiometrically), humus concentration - 2.23\% (by Hereus apparatus), content of available phosphorus $\left(\mathrm{P}_{2} \mathrm{O}_{5}\right)$ in the soil plough layer was 116 $\mathrm{mg} \mathrm{kg}^{-1}$, the content of available potassium $\left(\mathrm{K}_{2} \mathrm{O}\right)-85$ $\mathrm{mg} \mathrm{kg}^{-1}$ (determined in A-L extraction). Hemp followed winter wheat in the field rotation. Before sowing, complex fertilizers N9-P25-K25 (200 kg ha-1) have been applied.

Bi-factorial trial was carried out: Factor A - variety (A1 - USO 31; A2 - Bialobrzeskie); Factor B sowing rate $\left(\mathrm{B} 1-45 \mathrm{~kg} \mathrm{ha}^{-1} ; \mathrm{B} 2-70 \mathrm{~kg} \mathrm{ha}^{-1}\right)$. Both of selected varieties are monoecious,

Hemp was sown on $7^{\text {th }}$ of May in $15 \mathrm{~cm}$ inter-row spacing by single-row sowing machine. The size of trial plots was $2 \times 5=10 \mathrm{~m}^{2}$, the size of record plots $2 \times 4=8 \mathrm{~m}^{2}$ (trial was sown in tree replications). Randomised plot design was used. At both sides of the trial the protective plots of the same size as record plots were sown.

Hemp crop weediness (as well as crop density) was assessed after full crop emergence and at hemp harvest time. For this purpose 4 microplots of $0.25 \times$ $0.25 \mathrm{~m}$ were marked in each trial plot after full crop emergence. Hemp was harvested when the first matured seed appeared ( $26^{\text {th }}$ of August), and counting of weeds was done at the same time. The weeds for air-dry weight were picked up at hemp harvest and evaluated when weeds in the laboratory became airdry.

For statistical data evaluation the statistical software developed in the Lithuanian Institute of Agriculture was used, ANOVA method applied [19].

Mean air temperature and amount of precipitation were assessed during hemp growing period (Table 1).

Hemp germinated approximately in two weeks after sowing. It was warm and rainy in the middle of May (the amount of precipitation was twice more than the long-term average for second ten-day period of May). June was slightly cooler that long-term average but abundant in precipitation. It was warm in July and August, but the amount of precipitation was again huge, and even oversupply as the water for some time was flooding some surfaces on the trial field. Hemp and weeds were thriving over the vegetation period.

TABLE 1.

MEAN WEATHER TEMPERATURE AND PRECIPITATION DURING HEMP GROWING PERIOD Upytè, 2014

\begin{tabular}{|c|c|c|c|c|c|}
\hline \multirow[b]{2}{*}{ Month } & \multirow{2}{*}{$\begin{array}{c}\text { Ten-day } \\
\text { period }\end{array}$} & \multicolumn{2}{|c|}{$\begin{array}{l}\text { Mean weather } \\
\text { temperature, }{ }^{\circ} \mathrm{C}\end{array}$} & \multicolumn{2}{|c|}{ Rainfall, mm } \\
\hline & & 2014 & $\begin{array}{c}\text { Long- } \\
\text { term } \\
\text { average }\end{array}$ & 2014 & $\begin{array}{c}\text { Long- } \\
\text { term } \\
\text { average }\end{array}$ \\
\hline \multirow[t]{4}{*}{ May } & I & 8.2 & 11.0 & 23.5 & 16.0 \\
\hline & II & 13.8 & 12.6 & 34.0 & 16.0 \\
\hline & III & 16.8 & 13.5 & 7.5 & 18.0 \\
\hline & Aver./total & 12.9 & 12.4 & 65.0 & 50.0 \\
\hline \multirow[t]{4}{*}{ June } & $\mathrm{I}$ & 17.0 & 14.4 & 12.0 & 22.0 \\
\hline & II & 13.2 & 15.3 & 27.0 & 23.0 \\
\hline & III & 12.6 & 16.2 & 71.0 & 24.0 \\
\hline & Aver./total & 14.3 & 15.3 & 110.0 & 69.0 \\
\hline \multirow[t]{4}{*}{ July } & $\mathrm{I}$ & 19.0 & 17.2 & 49.5 & 25.0 \\
\hline & II & 18.8 & 18.0 & 20.0 & 25.0 \\
\hline & III & 21.9 & 18.0 & 23.0 & 26.0 \\
\hline & Aver./total & 19.9 & 17.7 & 92.5 & 76.0 \\
\hline \multirow[t]{4}{*}{ August } & $\mathrm{I}$ & 22.4 & 17.2 & 58.0 & 28.0 \\
\hline & II & 17.0 & 16.1 & 35.5 & 29.0 \\
\hline & III & 13.2 & 15.0 & 79.5 & 28.0 \\
\hline & Aver./total & 17.4 & 16.1 & 173.0 & 85.0 \\
\hline
\end{tabular}

\section{RESULTS AND DISCUSSION}

One of the investigated factors (Factor B, seed rate) could influence crop density, and, perhaps, crop weediness, thus the evaluated data of crop density are discussed also. The data of investigation show, that Factor B, seed rate, had a significant influence on crop density right after full emergence (Table 2). The mean crop density was 137 plants $\mathrm{m}^{-2}$ at seed rate of $45 \mathrm{~kg}$ $\mathrm{ha}^{-1}$, and significantly higher -216 plants $\mathrm{m}^{-2}-$ at seed rate of $70 \mathrm{~kg} \mathrm{ha}^{-1}$.

Also some significant interaction of tested factors was found - crop density was significantly higher when sowing hemp of both varieties at seed rate of 70 $\mathrm{kg} \mathrm{ha}^{-1}$, than that when sowing at $45 \mathrm{~kg} \mathrm{ha}^{-1}$.

The same significant differences have been found at hemp harvest time (Table 3). 
TABLE 2 .

CROP DENSITY (PLANTS $\mathrm{M}^{-2}$ ) AFTER FULL HEMP EMERGENCE UPYTE், 2014

\begin{tabular}{|c|c|c|c|}
\hline \multirow{2}{*}{$\begin{array}{c}\text { Variety } \\
\text { (Factor A) }\end{array}$} & \multicolumn{2}{|c|}{ Seed rate (Factor B) } & \multirow{2}{*}{$\begin{array}{c}\text { Mean for } \\
\text { Factor A }\end{array}$} \\
\cline { 2 - 3 } & $45 \mathrm{~kg} \mathrm{ha}^{-1}$ & $70 \mathrm{~kg} \mathrm{ha}^{-1}$ & 172.5 \\
\hline USO 31 & 121.7 & $223.3^{*}$ & 180.7 \\
\hline Bialobrzeskie & 152.0 & $209.3^{*}$ & - \\
\hline Mean for Factor B & $136.8^{*}$ & $216.3^{*}$ & $\begin{array}{c}\text { ( } \\
\mathrm{R}_{05} \text { (seed rate) } \\
\text { rate) }=25.36\end{array}$ \\
\hline $\mathrm{R}_{05}$ (variety) $=14.64 \mathrm{R}_{05}$ (variety x seed \\
\hline
\end{tabular}

* - significant at 0.05 probability level;

TABLE 3.

CROP DENSITY (PLANTS $\mathrm{M}^{-2}$ ) AT HEMP AT HARVEST UPYTE், 2014

\begin{tabular}{|c|c|c|c|}
\hline \multirow{2}{*}{$\begin{array}{c}\text { Variety } \\
\text { (Factor A) }\end{array}$} & \multicolumn{2}{|c|}{ Seed rate (Factor B) } & \multirow{2}{*}{$\begin{array}{l}\text { Mean for } \\
\text { Factor A }\end{array}$} \\
\hline & $45 \mathrm{~kg} \mathrm{ha}^{-1}$ & $70 \mathrm{~kg} \mathrm{ha}^{-1}$ & \\
\hline USO 31 & 104.7 & $195.0 *$ & 149.8 \\
\hline Bialobrzeskie & 130.3 & $179.7^{*}$ & 155.0 \\
\hline Mean for Factor B & $117.5^{*}$ & $187.3^{*}$ & - \\
\hline $\mathrm{R}_{05}($ variety $)=17.2$ & \multicolumn{3}{|c|}{$\begin{array}{l}\mathrm{R}_{05}\left(\text { seed rate) }=17.23 \quad \mathrm{R}_{05} \text { (variety } \mathrm{x} \text { seed }\right. \\
\text { rate) }=29.85\end{array}$} \\
\hline
\end{tabular}

Weed number counted in trial plots at full hemp emergence varied from 140 to 166 plants $\mathrm{m}^{-2}$. Significantly more weeds (in average 166 plants $\mathrm{m}^{-2}$ ) were found in the plots with seed rate of $45 \mathrm{~kg} \mathrm{ha}^{-1}$, and consequently lower crop density, and under 140 weed plants $\mathrm{m}^{-2}$ were found in the plots with seed rate of $70 \mathrm{~kg} \mathrm{ha}^{-1}$, and consequently higher crop density (Table 4). Variety, as a Factor, didn't have any influence on crop weediness at full crop emergence.

TABLE 4.

CROP WEEDINESS (PLANTS $\mathrm{M}^{-2}$ ) AT FULL HEMP EMERGENCE UPYTE், 2014

\begin{tabular}{|l|c|c|c|}
\hline \multirow{2}{*}{$\begin{array}{c}\text { Variety } \\
\text { (Factor A) }\end{array}$} & $45 \mathrm{~kg} \mathrm{ha}^{-1}$ & $70 \mathrm{~kg} \mathrm{ha}^{-1}$ & $\begin{array}{c}\text { Mean for } \\
\text { Factor A }\end{array}$ \\
\cline { 2 - 4 } USO 31 & 167.3 & 141.3 & 154.3 \\
\hline Bialobrzeskie & 165.3 & 138.3 & 151.8 \\
\hline Mean for Factor B & $166.3^{*}$ & $139.8^{*}$ & - \\
\hline $\mathrm{R}_{05}$ (variety) $=12.28$ & $\begin{array}{c}\mathrm{R}_{05}\left(\text { seed rate) }=12.28 \mathrm{R}_{05} \text { (variety x seed }\right. \\
\text { rate) }=21.27\end{array}$ \\
\\
${ }^{*}$ - significant at 0.05 probability level;
\end{tabular}

Hemp crop weediness at harvesting time was much lower than that at the beginning of vegetation (Tables 5 and 4), but still abundant (12-23 plants $\left.\mathrm{m}^{-2}\right)$. Similar amount was found at harvest in previous our investigations [20]. Perhaps, rainy period was favourable not only for hemp growing, but for weeds as well.

TABLE 5.

CROP WEEDINESS (PLANTS $\mathrm{M}^{-2}$ ) AT HEMP HARVEST UPYTE், 2014

\begin{tabular}{|l|c|c|c|}
\hline \multirow{2}{*}{$\begin{array}{c}\text { Variety } \\
\text { (Factor A) }\end{array}$} & \multicolumn{2}{|c|}{ Seed rate (Factor B) } & Mean for \\
\cline { 2 - 3 } & $45 \mathrm{~kg} \mathrm{ha}^{-1}$ & $70 \mathrm{~kg} \mathrm{ha}^{-1}$ & Factor A \\
\hline USO 31 & 23.3 & 12.0 & 17.7 \\
\hline Bialobrzeskie & 18.7 & 14.0 & 16.3 \\
\hline Mean for Factor B & 21.0 & 13.0 & - \\
\hline $\mathrm{R}_{05}$ (variety) $=6.94$ & $\begin{array}{c}\mathrm{R}_{05} \text { (seed rate) }=6.94 \quad \mathrm{R}_{05} \text { (variety x seed } \\
\text { rate) }=12.02\end{array}$ \\
\hline
\end{tabular}

Again more weeds were in the plots with lower seed rate, but the differences were not significant.

Reduction of hemp crop weediness during vegetation period was emphatic - in average 136 weed plants $\mathrm{m}^{-2}$. The tendency is visible that reduction of crop weediness was higher $\left(145\right.$ weed plants $\left.\mathrm{m}^{-2}\right)$ in thinner crop and smaller (127 weed plants $\left.\mathrm{m}^{-2}\right)$ - in denser crop (Table 6).

TABLE 6.

REDUCTION OF HEMP CROP WEEDINESS (PLANTS ${ }^{-2}$ ) SINCE FULL GERMINATION UNTIL HARVEST UPYTE், 2014

\begin{tabular}{|c|c|c|c|}
\hline \multirow{2}{*}{$\begin{array}{c}\text { Variety } \\
\text { (Factor A) }\end{array}$} & \multicolumn{2}{|c|}{ Seed rate (Factor B) } & \multirow{2}{*}{$\begin{array}{c}\text { Mean for } \\
\text { Factor A }\end{array}$} \\
\cline { 2 - 3 } & $45 \mathrm{~kg} \mathrm{ha}^{-1}$ & $70 \mathrm{~kg} \mathrm{ha}^{-1}$ & 136,7 \\
\hline USO 31 & 144,0 & 129,3 & 135,5 \\
\hline Bialobrzeskie & 146,7 & 124,3 & - \\
\hline Mean for Factor B & 145,3 & 126,8 & - \\
\hline \multicolumn{2}{|c|}{$\mathrm{R}_{05}$ (variety) $=16.59$} & $\begin{array}{c}\mathrm{R}_{05} \text { (seed rate) }=16.59 \mathrm{R}_{05} \text { (variety x seed } \\
\text { rate) }=28,74\end{array}$ \\
\hline
\end{tabular}

The reduction of hemp crop weediness in ratio (in percent) to previous crop weediness (since full hemp emergence to harvest) was also calculated. It was rather similar in all plots (close to 87-90 percent) and nether seed rate (crop density) nor variety did not show influence on it (Table 7).

TABLE 7.

REDUCTION OF HEMP CROP WEEDINESS (\%) SINCE FULL GERMINATION UNTIL HARVEST UPYTE், 2014

\begin{tabular}{|l|c|c|c|}
\hline \multirow{2}{*}{$\begin{array}{c}\text { Variety } \\
\text { (Factor A) }\end{array}$} & \multicolumn{2}{|c|}{ Seed rate (Factor B) } & Mean for \\
\cline { 2 - 3 } & $45 \mathrm{~kg} \mathrm{ha}^{-1}$ & $70 \mathrm{~kg} \mathrm{~h}^{-1}$ & Factor A \\
\hline USO 31 & 85.8 & 91.5 & 88.6 \\
\hline Bialobrzeskie & 88.3 & 89.8 & 89.0 \\
\hline Mean for Factor B & 87.0 & 90.6 & - \\
\hline $\mathrm{R}_{05}$ (variety) $=4.89$ & $\begin{array}{c}\mathrm{R}_{05} \text { (seed rate) }=4.89 \mathrm{R}_{05} \text { (variety x seed } \\
\text { rate) }=13.56\end{array}$ \\
\hline
\end{tabular}

Air-dry weight of weeds was significantly lower $\left(4.5 \mathrm{~g} \mathrm{~m}^{-2}\right)$ in the plots of variety Bialobrzeskie sown at seed rate of $70 \mathrm{~kg} \mathrm{ha}^{-1}$. Data presented in Table 8 show clear tendency that air-dry weight of weeds was rather lower in the plots sown by higher seed rate (Table 8).

TABLE 8.

THE AIR-DRY WEEDS' WEIGHT $\left(\mathrm{G} \mathrm{M}^{-2}\right)$ UPYTE், 2014

\begin{tabular}{|c|c|c|c|}
\hline \multirow{2}{*}{$\begin{array}{c}\text { Variety } \\
\text { (Factor A) }\end{array}$} & \multicolumn{2}{|c|}{ Seed rate (Factor B) } & \multirow{2}{*}{$\begin{array}{l}\text { Mean fol } \\
\text { Factor A }\end{array}$} \\
\hline & $45 \mathrm{~kg} \mathrm{ha}^{-1}$ & $70 \mathrm{~kg} \mathrm{ha}^{-1}$ & \\
\hline USO 31 & 23.3 & 8.8 & 16.1 \\
\hline Bialobrzeskie & 11.9 & $4.5^{*}$ & 8.2 \\
\hline Mean for Factor B & 17.6 & 6.7 & - \\
\hline \multicolumn{4}{|c|}{$\begin{array}{c}\mathrm{R}_{05}(\text { variety })=5.77 \mathrm{R}_{05}(\text { seed rate })=5.77 \mathrm{R}_{05}(\text { variety } \mathrm{x} \text { seed } \\
\text { rate })=10.00\end{array}$} \\
\hline \multicolumn{4}{|c|}{$*_{-}$- significant at 0.05 probability level; } \\
\hline
\end{tabular}

Seed rate had a significant influence on crop density at full hemp emergence as well as at harvesting time. Rainy vegetation period was favourable not only for hemp growing, but for weeds as well. Crop density (as a result of seed rate) had a significant influence on 
crop weediness - significantly more weeds (in average 166 plants $\mathrm{m}^{-2}$ ) were found in the plots with seed rate of $45 \mathrm{~kg} \mathrm{ha}^{-1}$, and consequently lower crop density, and under 140 weed plants $\mathrm{m}^{-2}$ were found in the plots with seed rate of $70 \mathrm{~kg} \mathrm{ha}^{-1}$, and consequently higher crop density. Hemp crop weediness at harvesting time was much lower than that at the beginning of vegetation; reduction of weediness over the vegetation period was close to $87-90$ percent.

\section{REFERENCES}

[1] I. Bocsa and M. Karus, "Hemp cultivation" in: The cultivation of hemp: botany, varieties, cultivation and harvesting. Sebastopol, USA, 1998, $186 \mathrm{p}$.

[2] V. Mediavilla, M. Jonquera, I. Schmid-Slembrouck, and A. Soldati, "Decimal code for growth stages of hemp (Cannabis sativa L.)", Journal of the international hemp association, vol. 5 , no. 2 , pp. $65,68-74,1998$.

[3] Z. Jankauskienè and E. Gruzdevienè, "Evaluation of Cannabis sativa cultivars in Lithuania". Zemdirbyste-Agriculture, vol 97, no. 3, pp. 87-96, 2010.

[4] L. Poiša and A. Adamovičs, "Hemp (Cannabis sativa L.) as an Environmentally Friendly Energyplant”. Scientific Journal of Riga Technical University. Environmental and Climate Technologies, 5, pp. 80-85, 2010.

[5] M. S. U. Rehman, N. Rashid, A. Saif, T. Mahmood and J.-I Han, "Renewable and Sustainable Energy Reviews". Renewable and Sustainable Energy Reviews, vol. 18, pp. 154 164, 2013.

[6] H. Burczyk, L. Grabowska, M. Strybe and W. Konczewicz, "Effect of sowing density and date of harvest on yields of industrial hemp". Journal of Natural Fibers, vol. 6, pp. 204218, 2009.

[7] J. Hall, S. P. Bhattarai and D. J. Midmore, "Effect of industrial hemp (Cannabis sativa L) planting density on weed suppression, crop growth, physiological responses, and fibre yield in the subtropics", Renewable Bioresources, 2014 [Online]. Available: http://dx.doi.org/10.7243/2052-6237-2-1, [Accessed Feb 12, 2015].

[8] Hemp Factsheet. 2007. [Online]. Available: http://www.hempsisters.com/Information/factsheet.htm [Accessed: Feb. 14 2014].
[9] H. M. G. Van der Werf, W. C. A. van Geel and M. Wijlhuizen, "Agronomic research on hemp (Cannabis sativa L.) in the Netherlands, 1987-1993". Journal of the International Hemp Association, vol. 2, no. 1, pp. 14-17, 1995.

[10] Weed control. Manitoba Agriculture, Food and Rural $\begin{array}{lll}\text { Initiatives } & \text { [Online]. Available: }\end{array}$ http://www.gov.mb.ca/agriculture/crops/hemp/bko05s05.html. [Accessed: Feb. 13, 2014].

[11] Hemp agronomy 101. [Online]. Available: http://www.votehemp.com/PDF/HempAgronomy101version2 006. [Accessed: Feb. 14, 2014].

[12] T. Prade, "Industrial Hemp (Cannabis sativa L.) - a HighYielding Energy Crop", Doctoral Thesis, Swedish University of Agricultural Sciences Alnarp, 93 p., 2011.

[13] P. I. Peev, "Is industrial hemp a sustainable construction material?", Bachelor of Architectural Technology and Construction Management, Via University College, Horsens, Denmark, 36 p., 2012.

[14] T. Reeves, Hemp: an agricutural super-crop held hostage. 16 p., 2012.

[15] P. C. Struik, S. Amaducci, M. J. Bullard, N. C. Stutterheim, G. Venturi and H. T. H. Cromack, "Agronomy of fibre hemp (Cannabis sativa L.) in Europe", Industrial Crops and Products, vol.11, pp. 107-118, 2000.

[16] B. Sipos, E. Kreuger, S.-E. Svensson, K. Reczey, L. Bjornsson and G. Zacchi, "Steam pretreatment of dry and ensiled industrial hemp for ethanol production". Biomass and Bioenergy, vol. 34, no 12, pp. 1721-1731, 2010. DOI:10.1016/j.biombioe.2010.07.003

[17] K. Pudełko, L. Majchrzak and D. Narożna, "Allelopathic effect of fibre hemp (Cannabis sativa L.) on monocot and dicot plant species", Industrial Crops and Products, vol. 56, pp. 191-199, 2014.

[18] V. V. Buivydaitė, M. Vaičys, J. Juodis and A. Motuzas, Lietuvos dirvožemių klasifikacija. Vilnius, p. 76, 2001.

[19] P. Tarakanovas and S. Raudonius, Agronominiu tyrimy duomenu statistine analize taikant kompiuterines programas ANOVA, STAT, SPLIT-PLOT iš paketo SELEKCIJA ir IRRISTAT. Akademija, Kauno r. 58 p., 2003.

[20] Z. Jankauskienè, E. Gruzdevienè and S. Lazauskas, "Potential of industrial hemp (Cannabis sativa L.) genotypes to suppress weeds", Zemdirbyste-Agriculture, vol. 101, no. 3, pp. 265$270,2014$. 